\title{
SOLIDARY SELECTIVE COLLECTION AND THE INTEGRATED MANAGEMENT OF SOLID WASTE IN THE MUNICIPALITIES FROM THE FLUMINENSE COUNTRYSIDE AND THE ROLE OF THE COURT OF JUSTICE
}

\author{
D. ALVES*, J. A. F. SILVA, A. E. M. PINTO, M. A. S. MAURíCIO \\ Instituto Federal de Educação, Ciência e Tecnologia Fluminense \\ daysealves2012@gmail.com*
}

Submetido 14/08/2017 - Aceito 18/11/2018

DOI: $10.15628 /$ holos.2018.7528

\section{RESUMO}

By investing in the viability of social gains providing training and professional qualification aiming to sustainability, the Public Power promotes new values and attitudes that contribute to the improvement of the environment, citizenship and life quality. With this research it was sought to evaluate the collaborative role of the Court of Justice in implementing the solidary selective collection at Rio das Ostras' County Forum, in accordance with its Sustainable Logistics Plan, with the law that instituted the National Policy on Solid Waste and the Federal Constitution, under the guiding principles of Environmental Law. The methodological strategy adopted is based on exploratory and descriptive research with bibliographic review and the evaluation of qualitative and quantitative data. The study revealed that the Judiciary is a great generator of paper waste, and that the Forum produces daily almost $20 \%$ of the average generation of the entire region and that the involvement of the whole society is needed.

KEYWORDS: Sustainability, Dignity, Environmental Legal Principles.

\section{COLETA SELETIVA SOLIDÁRIA E GESTÃO INTEGRADA DE RESÍDUOS SÓLIDOS NOS MUNICÍPIOS DO INTERIOR FLUMINENSE E PAPEL DO TRIBUNAL DE JUSTIÇA}

\begin{abstract}
Ao investir na viabilização de ganhos sociais com formação e capacitação profissional visando a sustentabilidade, o Poder Público promove novos valores e atitudes que contribuem para o ambiente, cidadania e qualidade de vida. Com essa pesquisa buscou-se avaliar o papel colaborativo do Tribunal de Justiça na implantação da coleta seletiva solidária no Fórum da Comarca de Rio das Ostras, em atenção ao seu Plano de Logística Sustentável, à Lei que instituiu a Política Nacional de Resíduos Sólidos e à Constituição
\end{abstract}

Federal, à luz dos princípios norteadores do Direito Ambiental. A estratégia metodológica adotada está baseada em pesquisa exploratória e descritiva com revisão bibliográfica e avaliação de dados qualiquantitativos. O estudo revelou que o Poder Judiciário é grande gerador de resíduo do tipo papel, que o Fórum produz diariamente quase $20 \%$ da geração média de toda a região e que é necessário o envolvimento da sociedade.

PALAVRAS-CHAVE: Sustentabilidade, Dignidade, Princípios Jurídicos Ambientais. 


\section{INTRODUCTION}

The Law n. 12,305, from August 2nd, 2010, which established the National Solid Waste Policy (PNRS), provides the elaboration of integrated waste management plans, in order to establish solutions for the implantation of the solidary selective collection and brings several mechanisms to encourage the creation and organization of reusable and recyclable material collectors' cooperatives, in accordance with the constitutional principles of human dignity, intergenerational solidarity and the right to decent work, organized and recognized for lowincome workers (BRASIL, 2010).

The strategic planning from Rio de Janeiro State's Court of Justice (TJRJ) provides the improvement, expansion and diffusion of the agency's social programs to the countryside, promoting job training for the exercise of citizenship, hence it is necessary to invest for enabling social gains, including to the state's countryside that, despite its enormous importance for the national economic growth, has part of it's population living below the poverty line and getting livelihood for their families from the waste generated and inadequately discarded by other families. In this way, it is expected that the public power, especially the Judiciary, watches over the application of law, anchored in the principles of precaution, prevention, sustainability and human dignity, aiming at the sustainable development, information and community mobilization, by means of the integrated management of solid waste (TJRJ, 2016).

This research aimed to evaluate, under the light of the guiding principles from Environmental Law, relevant legislation and Sustainable Logistics Plan, the role of TJRJ in the implementation of Solidary Selective Collection at the Forum from Rio das Ostras' Municipality.

\section{SOLIDARY SELECTIVE COLLECTION}

Solidary selective collection is the collection, separation and disposal of materials that can be returned to the production cycle, destined to the associations and cooperatives of collectors. It is also a way of including the population formed by citizens below the poverty line, based on the systemic view of integrated solid waste management that takes into account the political, economic, environmental, cultural and social dimensions (Brasil, 2006 and 2010; Correa, 2015; Portal Brasil, Justiça e Cidadania, 2011). 
The organization of waste pickers for the selective collection reduces the demand for sanitary landfills and complies with the constitutional principle of human dignity, as well as the finding of reusable and recyclable solid waste as an economic good with social value, labor and income generators, well as citizenship promoter, because when it's improperly discarded in the environment can compromisse population's life quality when contaminating water, air, soil and subsoil, causing diseases and floodings by the obstruction of drainage systems and by vectors proliferation (Brasil, 2010, Medeiros, 2016).

Table 1: Average of Urban Solid Waste Generation per capita Indices of in the Administrative Regions from Rio de Janeiro State in 2010 (PGIRS, 2013).

\begin{tabular}{|l|c|}
\hline \multirow{2}{*}{\multicolumn{1}{|c|}{ ADMINISTRATIVE REGIONS }} & GENERATION PER CAPITA INDICES \\
\cline { 2 - 2 } & (Kg/HAB/DAY) \\
\hline Metropolitan Region & 1,19 \\
\hline Fluminense Central South Region & 0,73 \\
\hline Costa Verde Region & 0,81 \\
\hline Coastal Offshore Region & 0,82 \\
\hline Middle Paraíba Region & 0,81 \\
\hline Northwest Fluminense Region & 0,72 \\
\hline Fluminense North Region & 0,87 \\
\hline Serrana Region & 0,82 \\
\hline STATE AVERAGE & 0,85 \\
\hline
\end{tabular}

Source: PGIRS, 2013. Adapted by the authors, 2017

By describing solid waste as trash Waldman (2010) says that it is all useless, discarded or scrap material. They are considered as useless and worthless, and refer to the dirty and smelly. Therefore, symbolically it also disqualifies the professional who deals with this material, generating contempt, distance and abandonment. However, it's needed to keep on mind that the waste picker is the begginer of the reuse cycle, he's the one who starts the process, the first responsible for the revaluation of the discarded product, which will pass through several segments until returning to the productive cycle (Brasil, 2010; Carmo, 2009).

In order to overcome the stigma, it is needed to apply the norms of the PNRS, creating and organizing collectors' cooperatives, incorporating constitutional precepts and environmental principles, making individuals and legal persons responsible, inserting them in the product life cycle, in order to reconcile interests, promote the exploitation and decrease the wastage. To this end, the law provides for the "articulation between the different spheres of public power" (Art.7, 
VIII) in the waste management, with the establishment of integrated solutions that contradict the paradigm of producing, consuming and disposing, including prioritizing recycled and recyclable in public procurement, and obliging large generators and federal, state and municipal entities to develop waste management plans (BRASIL, 2010). The National Policy on Solidary Economy aims to overcome extreme poverty and privation, and the organization of collectors contributes to the socialization, professionalization, political, environmental and cultural education of citizens excluded from the formal labor market, pointing the "Theory of the Benefit" which advocates that "the environmental quality for an individual should be understood as a measure, in money, of the increase of his well-being or of the services to which he may have access" (Braga, 2005, p.227; Senais, 2013).

And from the constitutional definition of sustainability and the dictates from the PNRS, it is up to the Public Power to plan and implement public infrastructure policies that ensure a healthy quality of life for the present and future generations, and favors economic and cultural interactions in the relationship between man and nature, since the wealth obtained through industrialization and consumption does not necessarily lead to degradation, then rich, educated, informed and conscientious people worry about the environment, invest in technologies and practice scientifically managed management to reduce degradation and poverty (Brasil, 1988; Milaré, 2011; Miller, 2008).

However, man's disastrous relationship to the environment is worsen by the current economic model based on incessant, successive, and progressive consumption, since even an low-injury damage, if repeatedly practiced, will result in an enormous damage over time, since society insists on dividing nature into three distinct and predatory moments: man as master and owner of the environment; nature as an inexhaustible source of resources; and the idea of nature as a waste disposal (Cunha, 2005; Sparemberger and Silveira, 2007).

\section{SOLID WASTE INTEGRATED MANAGEMENT}

The role of public managers is the planning of the best governance practices in a responsible way, seeking economic and social sustainability, with plans to be developed and implemented based on the law, especially the PNRS, which was elaborated based on the regionalization concept, aiming the cooperation arrangements of the public entities addressed to 
integrated management and social inclusion, based on the National Solid Waste Plan's model (Brasil, 2010; PNRS, 2011).

The reuse and recycling methodologies for materials and products need tools to be used on environmental management. And to think technically about sustainable public management requires the incorporation of the fundamental principles of Environmental Law to the strategic planning of the Administration, especially precaution, prevention, sustainability and human dignity.

The principles guide and ground the rules developed for the Law. It is the birth of the norm, of the science, the start, the beginning, where the ideas are organized to create a new scientific knowledge. Therefore, it serves as a guide both for the interpretation of the standard and in the absence of applicable standard, ensuring the fairness of decisions. In presenting itself as a new legal branch, Environmental Law has developed its own principles, aiming at the preservation of the human species, seeking new ways of living toghether with the environment, characterizing a paradigmatic change, since traditional legal sciences apply themselves mainly to assure the individual and patrimonial freedoms (Brasil, 1942; Brasil, 1943; Franco, 2004).

The principles of precaution and prevention translate the ethical and objective responsibility of the legal-institutional state so that we anticipate and prevent the occurrence of extremely probable damages, since it is an obligation for all of us to prevent irreversible environmental degradation or that of difficult reparation (Freitas, 2016). However, the principles are not confused. Prevention is anticipation of what is certain to happen. Caution is anticipated care with the unknown, is prudence, insufficient knowledge, uncertain, is insecurity about the dangers. For this reason is indicated the use of legislation instruments to guide the public entity in the application of the principles, such as waste management plan, land use control and city statute (Cunha, 2005; Milaré, 2011; Daltoé, 2012).

Precaution, prevention, harm, risk and responsibility are directly related to sustainability, insofar as the latter concept only exists if the first two exist and the harm and risk generate accountability. And in order to achieve economic, social and environmental sustainability, it is necessary to legally orient policies that lead to the internalization of negative externalities and reorient priorities in stimulating new choices. Sustainability as an educational philosophy of conscious use of resources is a Herculean attempt to review all capitalist logic from endogenous changes in the citizen's practice of consuming, with guardianship of fundamental rights, that 
adopts sustainability as a principle, where development means pricing the inoperance and readjusting public policies (Canotilho, 2010; Pereira et al, 2012; Freitas, 2016).

Among the fundamental rights, human dignity stands out in the democratic legal order, because it has "its secular cradle in philosophy. It is, in the first place, a value, linked to the idea of good, just, virtuous, situated alongside Law central values, such as justice, security and solidarity" (Barroso, 2010, p.10).

According to Antunes (2010), the constitutional right to the environment emanates from the basic principle of human dignity, from which all other principles of Environmental Law are derived, then, in order to support recognized rights, legal principles are needed, with the direct participation of all social actors. Thus, the importance of associated management and of consortium practices in the provision of services is emphasized, since they help the development of infrastructure projects required by the population (Borges, 2006).

The PNRS evidences and stimulates joint actions of public entities. The legislative strategy itself creates mechanisms of interrelation and interdependence between the norms, which reveals the hermeneutic strategy of the legislator to implement the whole policy, then, to operate a legal diploma it is needed that the other exists, for example, to have waste management, it is needed to have basic sanitation, associated management and social control (Milaré, 2011).

Aiming at a more effective action, and based on the information that the State sends about $80 \%$ of the nearly 12,000 tons of waste produced daily, a Master Plan for Solid Waste Integrated Management was launched for Rio de Janeiro's Metropolitan Region, what provides long life to landfills and income to the professional waste pickers. The plan is very comprehensive and well detailed, emphasizing the proposal of management through regionalization and the creation of public consortia as a way to promote and stimulate regional partnerships (PEGIRS, 2013).

\section{SUSTAINABLE LOGISTICS PLAN FROM RIO DE JANEIRO STATE COURT OF JUSTICE}

Brazil began to technically think a sustainable public management at the United Nations Conference on Environment and Development, held in Rio de Janeiro in 1992, when Agenda 21 
was elaborated, which main challenge is the planning aiming to shared action, so that government and society, in a co-responsibility system, seek to harmonize economy, environment and social justice (Agenda 21, 2018).

Based on Agenda 21, the Public Administration Environmental Agenda (A3P) was created in 1999, as an environmental management program of the Public Administration for a new institutional culture, which has among its guidelines the adequate management of waste. In 2007, the National Justice Council (CNJ) issued the Recommendation No. 11 guiding the Courts to adopt public policies setting annual targets for environmental preservation and recovery in order to contribute to a more just and supportive society. Rio de Janeiro's Court of Justice (TJRJ) was the second court in the country to join the A3P in 2010. Thereafter, the same CNJ ruled on the obligation of the Judiciary Power agencies to implement Sustainable Logistics Plans, or PLS-PJ (A3P, 2018; CNJ, 2018).

The Judiciary Power acts at each municipality from Rio de Janeiro State, solving conflicts, impacting the environment and generating waste from its jurisdictional service activity and collection of near ten million processes. For this reason, in August 2015, the TJRJ approved a Sustainable Logistics Plan (PLS), which thematic axis number 2 is about waste management and aims to implement the selective collection at all the buildings of the Court until 2020. It also establishes that the agency provides the infrastructure needed to implement the Waste Management Plan, with procedures related to the correct disposal of waste, exposing the gency's responsibility for sustainability and consequently improving population's life quality (PLS, 2015).

4.1 The work environment and the waste generation at the notary offices from TJRJRio das Ostras's County Court

Rio das Ostras city is placed in the coastal offshore region from Rio de Janeiro State, is bathed by the Atlantic Ocean and has several Conservation Units and protected areas, such as Environmental Protection Areas, Relevant Ecological Interest Area, Municipal Park, Archaeological Sites and Rocky Coastlines' Natural Monument (Figure 1) (PMRO, 2018a). 


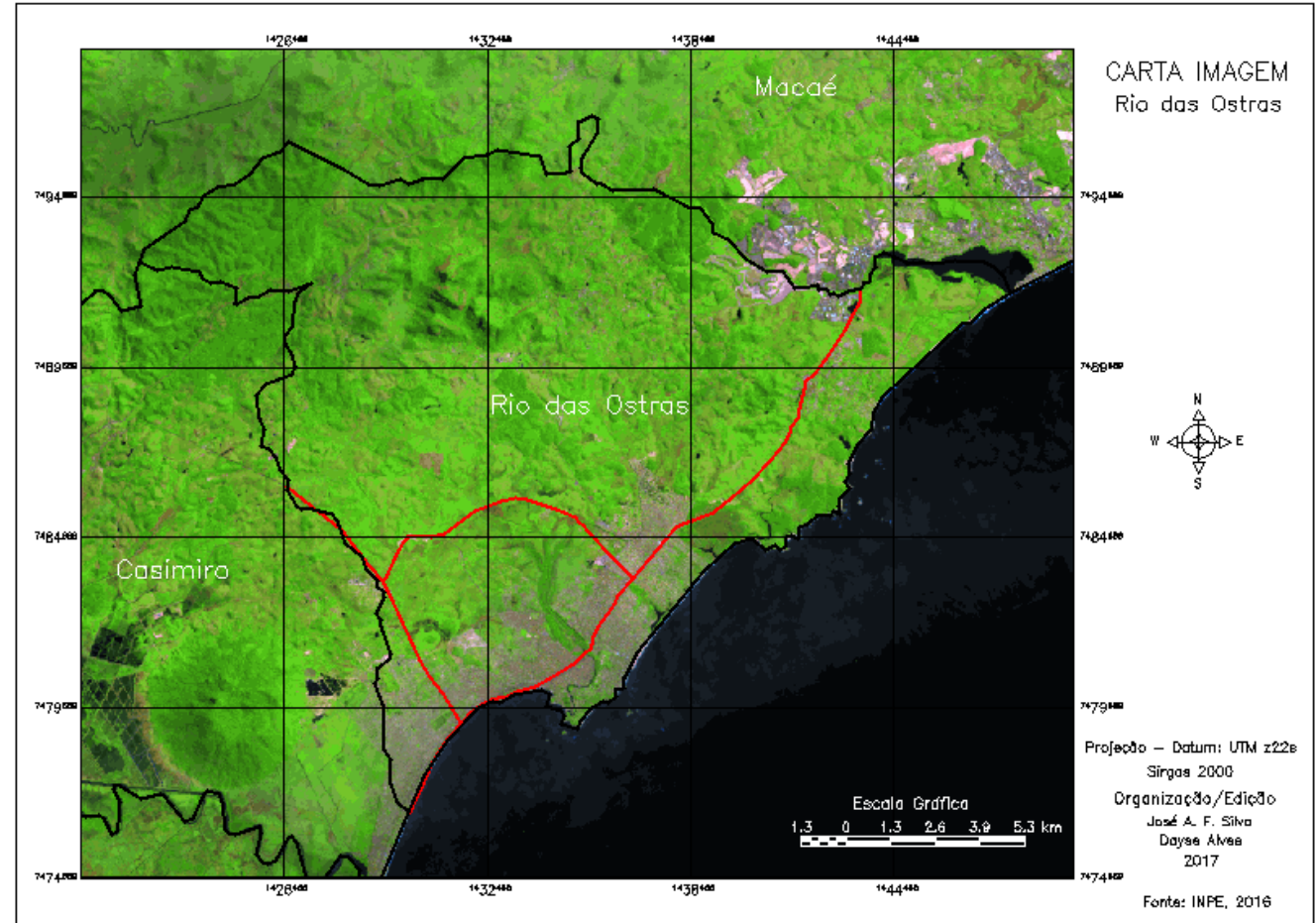

Figure 1: Image chart of Rio das Ostras municipality - RJ. Source: Authors, 2017.

The municipality was emancipated on April 10, 1992, and has recorded one of the highest demographic growth rates in the country between 2000 and 2010, justified both by the petroleum royalties levy from PETROBRAS (Campos Basin), located in the neighboring municipality of Macaé, and for the touristic development of the Lagos Region, another source of income for the municipality (PMRO, 2018b).

Accelerated growth and demographic concentration require efficient governance for the development of public policies that organize spaces, avoid social and environmental problems such as real estate speculation, excessive consumption of goods and services, and inappropriate waste disposal. The city has impressive numbers of population growth, urbanization and a good Human Development Index, HDI, but also shows degradation by irregular occupation, poor communities, street population, increased violence and final waste disposal in the streets, beaches and squares, although there is regular collection, sanitary landfill and municipal environmental legislation concerning inappropriate disposal (IDH, 2018).

The Rio das Ostras Forum has 14 (fourteen) service centers, conciliation rooms, several bathrooms, canopy, guardhouse and administration, where 187 people develop their work activities, among servers, judges, trainees, outsourced staff and public defenders, as well as an immeasurable floating population composed by parties and lawyers. 


\section{MATERIAL AND METHODS}

The study was carried out at Rio das Ostras County Forum, in Rio de Janeiro State countryside. The research was based on the empirical-phenomenological method with exploratory-descriptive characteristics with literature review, and gravimetric composition evaluation of the residues, aiming to identify quality, quantity and typology, and interviews with $43 \%$ (forty three percent) of the citizens that works at the place. To collect the data, it was necessary to apply semi-structured questionnaires to qualified interviews with key informants, reaching $100 \%$ (one hundred percent) of the Officers and Judges, as well as the Chief of the Environmental Management of Residues of the General Directorate of Logistics from TJRJ, representative of the technical staff that took part in the creation of the PLS, the accountable for Cleaning and Conservation of the building and the Pedagogical Coordinator for Environmental Education from the Environment Department of the Municipality, accountable for the collection in the city. Were also interviewed effective servants, temporarily ceeded servants, trainees, outsourced servants lawyers. In order to subsidize the study, a portable scale was used with daily weighing of the waste produced during a month, since the effective management of solid waste requires specific information about the amount of waste generated in the study area, besides the level of information, involvement and perception of the managers. By this method, the quantitative analysis showed that almost all waste is composef of paper, with a small amount of organic and plastic waste.

Three semi-structured questionnaires, composed of direct and open questions, were applied according to the target audience, one for the Judges, the other for managers and servers in general, and a specific third for the representative of the municipality.

\section{RESULTS AND DISCUSSIONS}

Solid Waste is one of the main environmental concerns in the contemporary world. Discarded garbage is a result of the industrial production in the current economic model, causing irreversible damage and offering global risks, sometimes invisible and imperceptible. Hence, the search for intercultural dialogue, for a new social legitimation and for universal solidarity, based on responsible consumption and disposal. 
The National Solid Waste Plan, which should serve as a model for state, regional, intermunicipal and municipal plans, has among its goals the content presented in the PNRS, including an obligation for municipalities to present waste treatment practices by 2014 . However, Opinion No. 385/2015, with the final redaction of the Federal Senate Bill 425/2014 extends the term for municipalities as Rio das Ostras until the year 2019.

At Rio das Ostras Forum, each office has about 15 (fifteen) trash cans for paper and 01 (one) for waste from snacks and meals, which is not even filled at the end of the day. There is a timid reutilization of paper in the registry activities, mainly by the drafts making.

By gathering the information contained in the responses to the questionnaires, it was possible to verify that although the Court has a Sustainable Logistics Plan since 2015, with several social actions performed, it's not known by all off them, as well as other important information to the environmental citizenship practice. It should be emphasized that, for managers and Judges in office, it is the Court's obligation implementing the selective collection at the Forum and make feasible the Agreement with the Municipality.

The magistrates were unanimous in affirming that the solidary selective collection meets the principle of human dignity and its non-implementation, in the form of the law, marks the omission of the public entities, as well as the organization of collectors in cooperatives or in other forms of association can coat the profession of dignity and win the society's respect.

They also state that integrated management can solve the waste problem in the cities, and that the National Policy on Solidarity Economy can contribute to the decrease of misery, as the Court's social programs help on self-esteem increase and recidivism reduction. When asked about what is the greatest obstacle to the implementation of solidary selective collection, magistrates answered that the issue is economic, and a niche should be created in the market to measure profit; there is inefficiency and lack of political will associated with the disarrangement of public entities; and that the Court must provide more information on the subject.

The data collection revealed that, at Rio das Ostras city Court, 187 (one hundred and eighty-seven) employees perform their functions, producing daily, on average, $28.23 \mathrm{~kg}$ of solid waste, mainly paper, that is, $0.15 \mathrm{~kg} /$ day / employee, which corresponds to $18.29 \%$ of the average generation of Coastal Offshore Region, which is 0.82 / kg / inhab / day.

The Judiciary is a major generator of a specific type of waste because of its primary activity, whose typology is practically composed of paper, a phenomenon commom to all forums. The 
Court of Justice has a Sustainable Logistics Plan, with the forecast of implementing selective collection in all units until 2020. The implementation experience in other forums can subsidize and assist the implementation in Rio das Ostras.

The inclusion of the fundamental right to the environment in the Constitution imposes on the Public Power and the community the duty of defending and preserving it, and it is needed to provide knowledge that encourages active participation on environmental issues, since very little progress has been made in the disposal, reuse and citizens' positioning, questioning values, reducing consumption and waste, debating the policy and understanding the importance of implementing the Solidary Selective Collection for the improvement of the quality of life in the cities.

\section{FINAL CONSIDERATIONS}

With the present study, it was assessed that complying with the law is mandatory and, in the case of large waste producers such as the TJRJ, it is necessary to provide the necessary infrastructure for waste management in partnership with the municipalities, to avoid that the guardian of the law became a lawbreaker; to avoid that the one who applies the deadlines provided by law to citizens, does not meet even the deadlines set by itself in its Sustainable Logistics Plan.

It is also concluded that widespread dissemination and capacity building is needed for achieving community involvement, which must take responsibility for the product life cycle. These authors endorse that the principles, especially those of precaution and prevention, seek the utopic adage of producing more and better with fewer resources, generating less waste, by means of shared responsibility. And that society needs to review its forms of consumption, to favor selective collection and take part in the elaboration and implementation of efficient and feasible public policies, with infrastructure and social inclusion.

It's needed analyzing and evaluating the proposal of paradigmatic change of all economic and social logic, what provides a new look at the relationship between man and the environment, in the pursuit of sustainability based on human dignity.

The accomplishment of this research demonstrated that Rio das Ostras' municipality and the County's Forum are able to implement the solidary selective collection by means of an integrated management. The city has a sanitary landfill, a registered collectors' cooperative, although not operating due to lack of infrastructure and incentive, and several Voluntary Delivery 
Points, revealing structure and expertise able to withstand the segregation of the generated waste.

And since every major change starts with small attitudes, if we think about environment in a broad and global way we will realize that solid waste integrated management locally affects the lives of communities in a straight and positive way.

\section{REFERENCES}

A3P - Agenda Ambiental da Administração Pública. (2018). Available at: http://www.mma.gov.br/responsabilidade-socioambiental/a3p>. Accessed on: 09 jul. 2018.

Agenda 21. (2018). Available at: <http://ambientes.ambientebrasil.com.br/educacao/programas_ambientais/agenda_21_esc olar___implantacao.html>. Accessed on: 09 jul. 2018.

Antunes, P.B. (2010). Direito ambiental. Rio de Janeiro: Lumen Juris.

Barroso, L.R. (2010). A Dignidade da Pessoa Humana no Direito Constitucional Contemporâneo: Natureza Jurídica, Conteúdos Mínimos e Critérios de Aplicação. Provisional version for public debate. Mimeographed, dezembro de $2010 . \quad$ Available at: $<$ http://www.luisrobertobarroso.com.br/wpcontent/themes/LRB/pdf/a_dignidade_da_pessoa_humana_no_direito_constitucional.pdf> Accessed on: 28 jun. 2017.

Borges, A. G. (2006). Os consórcios Públicos na sua Legislação Reguladora. Available at: <http://www.direitodoestado.com/revista/RERE-6-SETEMBRO-2006-

ALICE\%20GONZALEZ.pdf>. Accessed on: 07 nov. 2016.

Braga, Benedito et al. 2005. Introdução à Engenharia Ambiental. São Paulo: Pearson Prentice Hall. $318 p$.

Brasil. 1942. Decreto-Lei no 4.657, de 4 de setembro de 1942. Lei de introdução às normas do Direito Brasileiro. Diário Oficial da União, 09/09/1942. Available at: http://www.planalto.gov.br/ccivil_03/decreto-lei/Del4657.htm>. Accessed on: 19 mai. 2018.

Brasil. (1943). Decreto-Lei n.o 5.452, de 1o de maio de 1943. CLT - Consolidação das leis do trabalho. Published in Diário Oficial da União, em 09/08/1943. Available at: <http://www.planalto.gov.br/ccivil_03/decreto-lei/Del5452.htm>. Accessed on: 18 mai. 2018.

Brasil. (1988). Constituição. República Federativa do Brasil. Published in Diário Oficial da União, 05/10/1988.

Available

at: <http://www.planalto.gov.br/ccivil_03/constituicao/constituicaocompilado.htm>. Accessed on: 19 mai. 2018.

Brasil. (2006). Decreto Federal no 5.940, de 25 de outubro de 2006. Institui a separação dos resíduos recicláveis descartados pelos órgãos e entidades da administração pública federal direta e indireta, na fonte geradora, e a sua destinação às associações e cooperativas dos catadores de materiais recicláveis, e dá outras providências. Published in Diário Oficial da 
União, 26/10/2006. Available at: <http://www.planalto.gov.br/ccivil_03/_ato20042006/2006/decreto/d5940.htm>. Accessed on: 19 mai. 2018.

Brasil. (2010). Lei no. 12.305, de 02 de agosto de 2010. Institui a Política Nacional de Resíduos Sólidos; altera a Lei no. 9.605, de 12 de fevereiro de 1998 e dá outras providências. Diário Oficial da União, 23/12/2010. Available at: <http://www.planalto.gov.br/ccivil_03/_ato20072010/2010/lei/l12305.htm>. Accessed on: 19 mai. 2018.

Canotilho, J. J.G. (2010). O Princípio da sustentabilidade como Princípio estruturante do Direito Constitucional. Available at: <http://www.scielo.mec.pt/scielo.php?pid=S164599112010000100002\&script=sci_arttext\&tlng=en>. Accessed on: 01 jul. 2017.

Carmo, M. S. (2009). A semântica 'negativa' do lixo como aspecto 'positivo' - um estudo de caso sobre uma associação de recicladores na cidade do Rio de Janeiro, Brasil. Available at: <http://www.apgs.ufv.br/index.php/apgs/article/view/7/101\#.WYy89G8rKdF>. Accessed on: 31 jul. 2017.

CNJ - Conselho Nacional de Justiça. (2018). Available at: <http://www.cnj.jus.br/busca-atosadm?documento=2795>. Accessed on: 09 jul. 2018.

Corrêa, M.P. (2015). Estudo de viabilidade para implementação de um centro didáticopedagógico para o gerenciamento integrado de resíduos sólidos no instituto federal fluminense - campus Macaé. 2015. Rio de Janeiro: Masters dissertation - PPEA - IFFluminense - IFF.

Cunha, P. R. (2005). A relação entre meio ambiente e saúde e a importância dos princípios da prevenção $e$ precaução. 2005.2 Available <http://www.fischeradvogados.com.br/artigo4.pdf>. Accessed on: 07 jul. 2017.

Daltoé, S. (2012). A aplicação do princípio da precaução nas políticas ambientais da União Europeia. Available at: <http://siaibib01.univali.br/pdf/Stefanie\%20Daltoe.pdf>. Accessed on: 09 jul. 2018.

Franco, A.R. (2004). Princípios do Direito Ambiental. Rev. de Ciên. Jur. e I. Rev. de Ciên. Jur. e Soc. da Un ipar. v.7, n.2, c. da Un ipar. v.7, n.2, p.205-218, jul./dez., 2004. jul./dez., 2004. Available at: <http://www.revistas.unipar.br/index.php/juridica/article/view/1330>. Accessed on: 07 jul. 2017.

Freitas, J. (2016). Sustentabilidade: direito ao futuro. 3a Ed. Belo Horizonte. Editora Fórum. 2016. $374 p$.

IDH - Índice de Desenvolvimento Humano. (2018). Indicadores Rio das Ostras. Available at: $<$ http://indicadores.cidadessustentaveis.org.br/br/RJ/rio-das-ostras > Accessed on: 09 jul. 2018.

Medeiros, C.R. (2016). Gestão de resíduos da construção civil: estudo de caso no município de Macaé, RJ. Rio de Janeiro: Masters dissertation - PPEA - IFFluminense - IFF.

Milarè, E. (2011). Direito do Ambiente: A gestão ambiental em foco: doutrina, jurisprudência, glossário. 7ạ Edição, revista, atualizada e ampliada. São Paulo. Editora Revista dos Tribunais. $1647 \mathrm{p}$.

Miller, G. T. (2008). Ciência Ambiental. Tradução da 11a edição norte-americana. Revisão técnica Welington Braz Carvalho Delitti. São Paulo: Cengage Learning, 123 p.

Pereira, A.O.K.; Calgaro, C.; Pereira, H.M.K. (2012). A sustentabilidade numa sociedade hiperconsumista.

Available

at: 
$<$ http://balcaodoconsumidor.upf.br/upload/revistas/74_consumosustentabilidade.pdf\#page=54>. Accessed on: 01 jul. 2017.

PEGIRS - Plano Estadual de Gestão Integrada de Resíduos Sólidos do Estado do Rio de Janeiro. (2013). Available at: <https://observatoriopnrs.files.wordpress.com/2014/11/rio-de-janeiroplano-estadual-de-resc3adduos-sc3b3lidos.pdf>. Accessed on: 19 jul. 2017.

PLS - Plano de Logística Sustentável do Tribunal de Justiça do Estado do Rio de Janeiro. (2015). Available at: <http://app.tjrj.jus.br/plano-log-sustentavel/>. Accessed on: 07 nov. 2016.

PMRO - Prefeitura Municipal de Rio das Ostras. (2018a). Available at: <https://www.riodasostras.rj.gov.br/>. Accessed on: 09 jul. 2018

PMRO - Prefeitura Municipal de Rio das Ostras. (2018b). Indicadores. Available at: $<$ http://indicadores.cidadessustentaveis.org.br/br/RJ/rio-das-ostras $>$. Accessed on: 09 jul. 2018.

PNRS - Plano Nacional de Resíduos Sólidos. (2011). Versão preliminar. Available at: <http://www.mma.gov.br/estruturas/253/_publicacao/253_publicacao02022012041757.pdf >. Accessed on: 07 nov. 2016.

Portal Brasil/Justiça e Cidadania. (2018). Available at: <http://www.brasil.gov.br/cidadania-ejustica/2011/10/coleta-seletiva-solidaria>. Accessed on: 09 jul. 2018.

Senais. (2013). Política Nacional de Economia Solidária, Ministério do Trabalho e Emprego, Secretaria Nacional de Economia, Termo de Referência, Volume 2. 2013. Available at: <http://trabalho.gov.br/images/Documentos/EconomiaSolidaria/AcoesIntegradasCatadores. pdf>. Accessed on: 28 mai. 2018.

Sparemberger, R.F.L.; Silveira, A.C. (2007). A relação homem e meio ambiente e a reparação do dano ambiental: reflexões sobre a crise ambiental e a teoria do risco na sociedade. Available at: <http://repositorio.furg.br/bitstream/handle/1/3806>. Accessed on: 01 jul. 2017.

TJRJ - Tribunal de Justiça do Estado do Rio de Janeiro. (2016). Available at: <http//www.tjrj.jus.br>. Accessed on: 09 nov. 2016. 